have listened to the priorities expressed by the chief executive officers of the research councils who, in turn, are briefed by their staffs. Both science minister and director general have access to the findings of the science and engineering base group of the OST.

As back up during this process, the science minister can draw on the policy summaries and briefing papers of the DTI's civil servants. The minister is also advised by the chief scientific adviser who has an office in both the DTI and the Cabinet Office and who is responsible directly to the prime minister. From his post in the Cabinet Office, the chief scientific advisor has a view of the science efforts across Whitehall. Both chief scientific advisor and science minister are supported by the transdepartmental science and technology group of the OST.

It is through this mesh of policy groups that the advice filters that leads to an allocation of funding among the research councils. "Dividing the science budget was a difficult decision," says Sainsbury. Once the alloca- tions are made, the research councils decide internally how to spend the money, but broad strategies laid down at the time of the funding allocation guide the decisions.

So much for the science budget. Science policy is also important for industry. The location of the science minister's office within the DTI reflects an article of faith both for this and the previous government that Britain's economic success rests on there being more commercial exploitation of the science base and closer links with industry.

The complex and iterative process of deciding the science budget applies at all levels in each of the elements of the UK's SET spend, including that spent to support the UK's participation in the European Union's fifth Framework programme. Preparations are now underway across government for the next CSR, which will be the Labour Party's blueprint for government spending from 2002 should it be re-elected. In short, there is plenty of work for science, engineering and technology policy-makers.

\section{Job search}

For further information about how to join the civil service fast stream, check: http://www.rasnet.co.uk/RAS/capitaras.html.

The Office of Science and Technology (OST)'s transdepartmental science and technology group, which is headed by Jo Durning, is considering making formal arrangements for taking secondees from universities, although she says that "this is currently only an idea". Further information on science policy can be found at http://www.hmtreasury.gov.uk/ $\mathrm{pub} / \mathrm{html} / \mathrm{csr} / 401101 . \mathrm{htm}$ and

http://www.dti.gov.uk/ost.

For general jobs in science policy, check the classified adverts of Nature and newspapers such as The Guardian (website addresses on listed on $p$. A3).

The OST's SET statistics are published by The Stationery Office and can be accessed online at http://www.dti.gov.uk/ost/SETstats98.

\title{
A view from the employers' side of the fence
}

\section{Results from a recent survey of large employers indicate the growth areas of employment and the level of competition that applicants should expect to face. The findings also highlight the skills that employers are seeking.}

A graduate's most important skills, say employers, are interpersonal skills, motivation and enthusiasm, and team working ability - in that order. The skills most often lacking but desirable, they say, are leadership ability and business awareness.

These findings emerge in a survey of large employers, like Logica and AstraZeneca, which are members of the Association of Graduate Recruiters (AGR). The strongest anticipated growth areas for employment are the public sector (19.4 per cent), areas of manufacturing (19 per cent), business services including finance and accountancy (18.5 per cent), and electrical and electronic engineering (13 per cent). The median predicted starting salary for undergraduates in 1999 was $£ 17,400$.

AGR is a professional association with a membership of about 600 mainly large company and public sector employers. Twice yearly, the Institute of Employment Studies undertakes a salaries and vacancies survey for the association. Some 263 firms participated in the last survey and 23 of these were interviewed to explore specific issues in depth in a qualitative fashion.

\section{Competition for jobs}

The survey shows that applicants face tough competition for jobs. On average, 67.9 people applied per vacancy, 14.8 people were short listed per job and 8.4 were interviewed. Although these may be daunting numbers for applicants, they imply a seemingly healthy state of affairs from the employers' perspective. Nevertheless, some vacancies remained unfilled from 1998 and

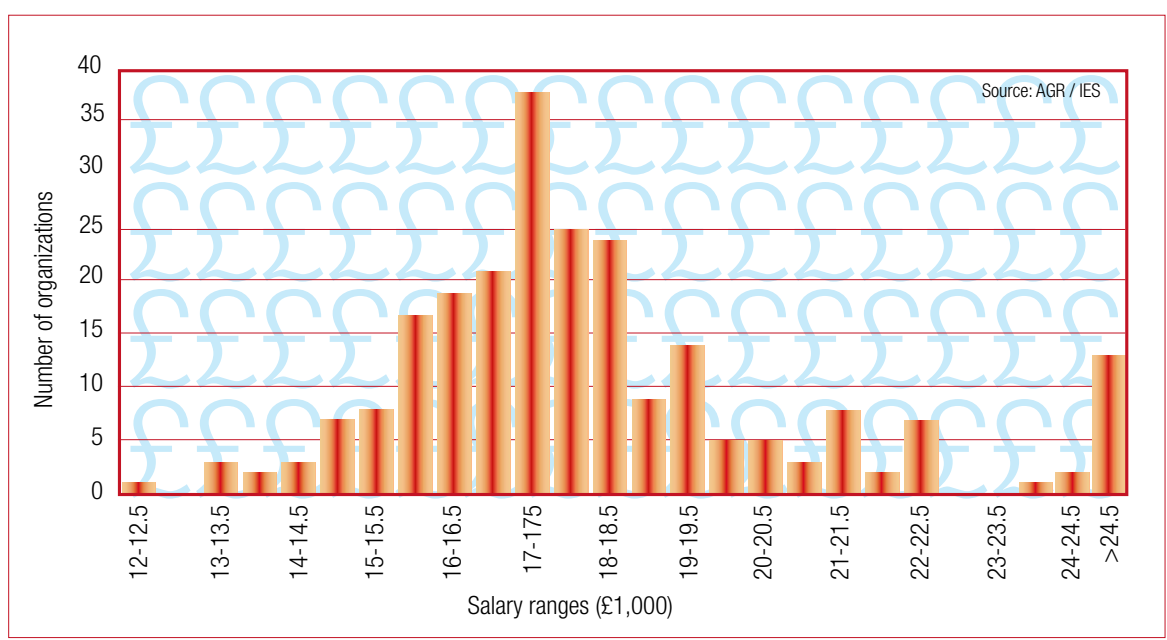

Forecast of graduate starting salaries for 1999. 


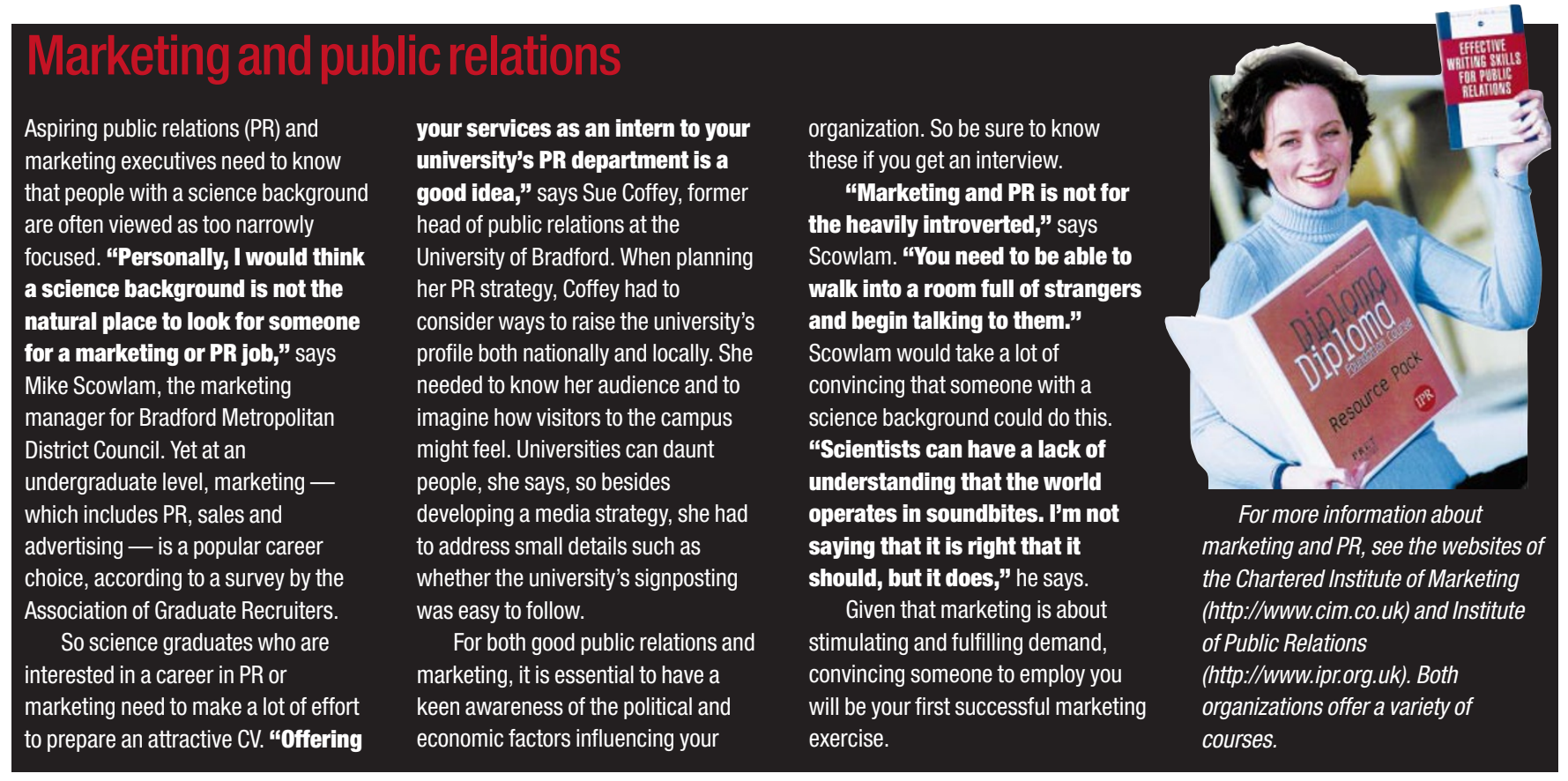

about a quarter of organizations expected vacancies to remain unfilled. "Employers won't take risks," says Carl Gilleard, the AGR's chief executive officer. "The investment is too high."

Interestingly, about a fifth of industrial organizations reported difficulties in recruiting to positions in science and research and development. Some 9 per cent of organizations reported major difficulties in recruiting the right candidate for jobs in electrical and electronic engineering, computer science and information technology,

\begin{tabular}{|c|c|c|}
\hline \multicolumn{3}{|c|}{$\begin{array}{l}\text { Three most important skills for graduate } \\
\text { recruiters }\end{array}$} \\
\hline Skill & $\begin{array}{l}\text { No. of } \\
\text { mentions }\end{array}$ & $\begin{array}{l}\text { Percentage of } \\
\text { organizations }\end{array}$ \\
\hline Team working & 96 & 39.8 \\
\hline Interpersonal skills & 92 & 38.2 \\
\hline Motivation \& enthusiasm & 88 & 36.5 \\
\hline Flexibility & 70 & 29.0 \\
\hline Customer orientation & 56 & 23.2 \\
\hline Business awareness & 53 & 22.0 \\
\hline Initiative and proactivity & 47 & 19.5 \\
\hline Problem solving & 44 & 18.3 \\
\hline Planning \& organization & 26 & 10.8 \\
\hline Numeracy & 24 & 10.0 \\
\hline Managing own development & 23 & 9.5 \\
\hline Leadership & 22 & 9.1 \\
\hline IT/computer literacy & 21 & 8.7 \\
\hline Oral communication & 20 & 8.3 \\
\hline Written communication & 12 & 5.0 \\
\hline Risk taking \& entrepreneurship & 6 & 2.5 \\
\hline Foreign languages & 5 & 2.1 \\
\hline Time management & 5 & 2.1 \\
\hline Other & 11 & 4.6 \\
\hline \multicolumn{3}{|c|}{$\begin{array}{l}\text { A total of } 241 \text { organizations were asked to identify the three most } \\
\text { important skills that they look for as graduate recruiters. The table } \\
\text { presents the number of times each skill/attribute was mentioned ( } N= \\
\text { 721) and the percentage of organizations mentioning each skill/attribute. } \\
\text { Source: AGR. }\end{array}$} \\
\hline
\end{tabular}

perhaps because high flyers are snapped up quickly into lucrative jobs.

By contrast, scarcely any companies reported difficulties recruiting to jobs in finance, accountancy and investment.

With median starting salaries of $£ 20,617$ in banking and finance compared with $\mathfrak{1 7 , 0 0 0}$ in engineering, it doesn't take a mathematician to make some connections. Admittedly, the median starting salary for accountants is only $\mathfrak{E} 15,500$, but this tends to rise with experience. Median starting salary for jobs in public services was $\mathfrak{1 5}, 691$.

\section{Searching the Internet}

How can one find lucrative banking, finance or accountancy jobs? The 'Milk Round' at the end of an undergraduate degree course is one route, but employers do not target all universities so be prepared to search the Internet sites of banks or accountancy firms. The AGR's survey shows that 156 of those employers surveyed use the Internet to describe typical vacancies in their organization and 113 advertised specific jobs. Firms plan to use the Internet increasingly for recruitment and to download completed application forms.

When you find the job, then you need the skills (see Table). Interpersonal skills and team work were rated by recruiters as highly desirable. One employer defined team work as the ability to work to a common goal, share responsibility and use individual strengths. Another said that interpersonal skills are the ability to communicate maturely and professionally with people at all levels of management and without giving offence.

"Often the graduate lacks confidence and the ability to demonstrate those skills or they undervalue the skills they have," says
Gilleard. Yet most graduates will have had experience of some part-time work. "There are very few jobs where team work is not important." It is, argues Gilleard, important to be aware of all the skills you have acquired. "You need to know what it is you have to sell...It's a switch off if you put yourself down."

\section{Job search}

Explore http://legacy.unl.ac.uk posted by the University of North London. The university has drawn on findings from sources such as the Association of Graduate Recruiters (AGR) and the 1995 Competitiveness White Paper to give visitors a sense of today's business world and the increasing emphasis on small businesses as employers. There is information about skills that are desirable for successful job applications and a student action plan for making yourself more employable.

The website at http://www.wdgd.csu.ac.uk is the start of a cascade that takes you to the Association of Graduate Careers Advisory Services (http://agcas.csu.ac.uk) and the AGR

(http://agr.csu.man.ac.uk). Also see the website of the Institute of Employment Studies at http://www.employment-studies.co.uk. There are too many company websites to give here, but they are easy to find with any standard search engine. If you don't know all the companies in a particular sector, take a look at the share price listings for the main players.

For articles and websites on alternative careers in law, patenting, banking, IT and journalism, see the Nature Careers and Recruitment feature 'Investigating the alternatives', available online at http://www.nature.com/jobs or in Nature 393, 493-498 (4 June 1998). 